\title{
Immunization of Female Mice with a Plasmid DNA Vaccine Coding Eight Repeats of Gonadotrophin Releasing Hormone (Gnrh-I) and Eight T-Helper Epitopes Suppress Fertility In Vivo
}

Mohammad Abu Hadi Khan ${ }^{*}$, Umme Kulsum Rima, Tadashi Kimura, Ayman M Gebril, Mohammad Taimur Islam, Abu Saleh Mahfuzul Bari and Valerie Anne Ferro

Department of Pathology, Faculty of Veterinary Science, Bangladesh Agricultural University, Mymensingh, Bangladesh

*Corresponding author: Mohammad Abu Hadi Khan, Professor, Department of Pathology, Faculty of Veterinary Science, Bangladesh Agricultural University, Mymensingh, Bangladesh, Tel: 880 (0)91 67401-6; Fax: +880 (0)9161510; E-mail: hadikhan68@yahoo.co.uk

Received date: 07 January 2015; Accepted date: 23 March 2015; Published date: 26 March 2015

Copyright: (c) 2015 Hadi Khan MA, et al. This is an open-access article distributed under the terms of the Creative Commons Attribution License, which permits unrestricted use, distribution, and reproduction in any medium, provided the original author and source are credited.

\begin{abstract}
Induction of an appropriate immune response against gonadotrophin releasing hormone (GnRH-I) disrupt fertility, reduce fecundity and regress tumours of reproductive system. To disrupt fertility a plasmid DNA vaccine was engineered coding eight repeats of $\mathrm{GnRH}-\mathrm{I}$ and eight T-helper epitopes. Translation efficiency of the vaccine was evaluated in undifferentiated COS1 cells and found to release $\mathrm{GnRH}-\mathrm{I}$ fusion protein in culture supernatant. Swiss

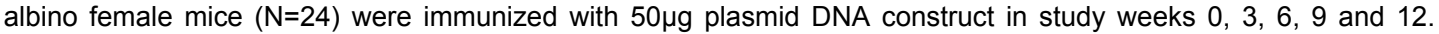
Group 2 mice were primed with the plasmid DNA in hemagglutinating virus of japanese envelope (HVJE) vector and subsequent boosts were carried out in phosphate buffer saline. Group 3 mice were immunized with the plasmid DNA in non-ionic surfactant vesicles (NISV) and Group 1 was served as untreated control. The effect of immunization was studied in terms of anti-GnRH-I antibody response (OD value at A540 \pm SD), suppression of ovarian folliculogenesis, altered uterine histoarchitecture and impaired fertility in vivo in mating trials. In study week $24 \mathrm{OD}$ values of anti$\mathrm{GnRH}-\mathrm{I}$ antibody response were $0.982 \pm 0.231$ in Group 3 mice, followed by $0.783 \pm 0.191$ in Group 2 in comparison with no response in Group 1 controls $(0.237 \pm 0.147)$. Results of mating trials showed conception failure in vaccinated mice; 51,18 and 05 pups were seen in the uteri of Groups 1, 2 and 3 mice respectively. There was significant $(p>0.001)$ reduction in the weight of ovaries in Group $2(8.50 \pm 2.38 \mathrm{mg})$ and Group $3(7.25 \pm 0.95 \mathrm{mg})$ mice compared to Group 1 control $(15.00 \pm 1.41 \mathrm{mg})$. Significant reduction of ovarian folliculogenesis was seen in Group 2 ( $p>0.001$ ) and Group 3 mice $(p>0.01)$. In conclusion, the plasmid DNA vaccine delivered in female mice with HVJE and NISV induced significantly $(p>0.001)$ higher levels of anti-GnRH-I antibody response, suppressed ovarian and uterine function and impaired fertility in vivo.
\end{abstract}

Keywords: Mice; DNA vaccine; GnRH-I; In vivo fertility; Ovarian folliculogenesis

\section{Introduction}

It has now been over two decades since plasmid DNA vaccines were described as an inducer of effective immune response [1]. This type of vaccine has since been shown to hold promise for the treatment of cancer [2], allergies [3], prevention of infectious diseases [4], neutralization of fecundity of mammals $[5,6]$ and suppression of fertility [7]. GnRH-I is the releaser of both luteinizing hormone (LH) and follicle stimulating hormone (FSH) and is a key peptide of reproduction [8]. GnRH-I immunoneutralization has, therefore, been used to neutralize fecundity of many domestic and wild mammals especially to prevent taint in meat (boars, lamb and muton), reduce sexual aggressiveness of farm animals $[9,10]$ and to control feral animal populations [11]. Moreover, GnRH-I and its receptors are expressed in a number of malignant tumours of the breast, ovary, endometrium and prostate in mammals [12] and these have all contributed to a significant interest in neutralizing GnRH-I to control tumour growth $[13,14]$.

Immunoneutralization of GnRH-I using GnRH-I peptide carrier conjugates is inefficiet in terms of variable chemical conjugation and heterogeneity of antigen preparations [14]. These problem can partially be obviated by using GnRH-I fusion proteins [9]. Both the antigens require adjuvants $[6,9,15]$ to induce sufficient immunity and are not suitable for clinical application. One successful strategy to neutralize GnRH-I in mammals is the use of DNA vaccine $[6,7,16]$. However, DNA vaccines used in experimental trials are not equally efficient to induce robust antigen-specific immune response [3,17]. A number of methods have been used to enhance immunity of DNA vaccines including electroporation [18], use of non-viral [19] or synthetic vectors [20] and properties of encoded antigens [21]. Previously plasmid DNA vaccines were constructed coding four to five GnRH-I repeats $[7,16]$ and following immunization the antibody response kinetics were slightly delayed. To overcome these disadvantages a new vaccine was constructed coding eight repeates of GnRH-I and the vaccine were delivered in a hemagglutinating virus of japanese envelope (HVJE) vector [19] and in a lipd based delivery system [20]. The level of GnRH-I immunoneutralisation was evaluated by means of anti-GnRH-I antibody responses, suppression of ovarian folliculogenesis and disruption of fertility in adult female mice.

\section{Materials and Method}

\section{Designing, engineering and amplifing of the vaccine}

A plasmid DNA vaccine coding four repeats of GnRH-I [16] was digested with Xbal enzyme and amplified with Tag A (5/gcggccgctatctagaatgaagccaatt-3/) and Tag B (5/- 
Citation: Umme Kulsum Rima, Tadashi Kimura, Ayman M Gebril, Mohammad Taimur Islam, Abu Saleh Mahfuzul Bari, Valerie Anne Ferro, Mohammad Abu Hadi Khan (2015) Immunization of Female Mice with a Plasmid DNA Vaccine Coding Eight Repeats of Gonadotrophin Releasing Hormone (Gnrh-I) and Eight T-Helper Epitopes Suppress Fertility In Vivo. J Vaccines Vaccin 6: 282. doi:2157-7560.1000282

Page 2 of 7

ttctcgagctctagacgatgcacgatc-3/) oligonucleotides to develop Not1 and Xhol cutting sites at $5 /$ and $3 /$ ends respectively. The end labeled oligonucleotides were than digested with Not1 and Xho1 enzymes and ligated into the upstream of the vaccine construct [7] at Not1 and Xhol sites. The vaccine construct engineered incorporating GnRH-I leader sequences, eight repeats of GnRH-I interpersed with eight Thelper epitopes, an $\mathrm{N}$ terminal V5 epitope and a histidine tag before stop codon (Figure 1). The T-helper epitopes were derived from circumsporozoite protein (CSP), respiratory syncitial virus (RSV), measles virus protein (MVP) and tetanus toxoid (TT) [6]. Competence JM109 E. coli was transformed with the vaccine construct and amplified in LB medium containing ZeocinTM $(40 \mu \mathrm{g} / \mathrm{ml}$, Invitrogen Life technologies, USA). The plasmid DNA was extracted from the bulk culture of transformed $E$. coli using wizard plus Gigaprep kit (Promega, USA). A colony PCR was designed to amplify $981 \mathrm{bp}$ long fragment from the transformed $E$. coli using forward (5'taatacgactcactataggg- $\left.3^{\prime}\right)$ and a reverse primers (5'acgatcacgcctttgatttc-3'). The complete GnRH-I and T-helper coding genes, the positions of the start and stop codons and the integrity of the open reading frames on to pcDNAV5-HisB plasmid were determined by sequence analysis.

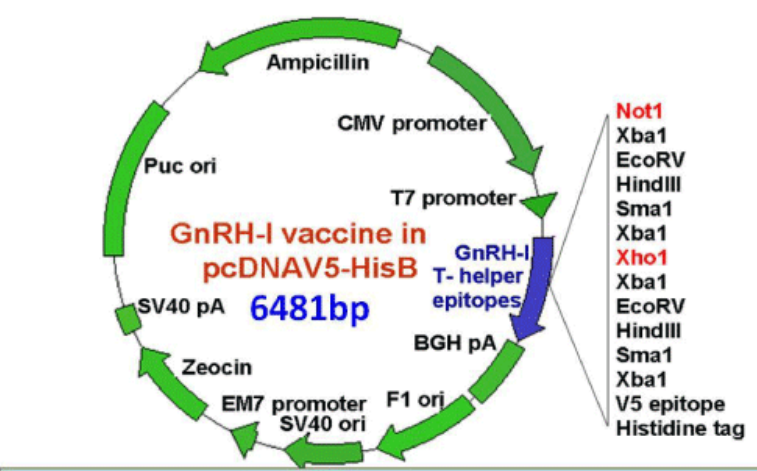

Not1 (0) - Xba1 (9) - EcoRV (125) - HindIII (186) - Sma1 (313) - Xba (449) - Xho1 (456) - Xba1 (462) - EcoRV (578) - HindIII (639) - Sma1 (766) - Xba1 (902)-V5 epitope (921)-Histidine tag (923)-Termination

Figure 1: The 6,481bp long pcDNAV5-HisB plasmid map indicating relative positions of the vaccine construct (blue color, GnRH-I). The restriction enzyme digestion sites with the V-5 epitope and a histidine tag in the pcDNAV5-HisB plasmid was marked below the plasmid modules.

Amino acid sequence of the vaccine: The blue letters indicate the sequences of the GnRH-I peptide and hhhhhh represents a histidine tag.

Mkpiqkllaglilltscvegcssqhwsyglrpggsgdiekkiakmekassvfnvvngklsgeh wsyglrpgsgaeynvfhnktkelpraggehwsyglrpgggqyikanskfigitelgsgehwsygl rpggsglseikgvivhrlelesrmkpiqkllaglilltscvegcssqhwsyglrpggsgdiekkiak mekassvfnvvngklsgehwsyglrpgsgaeynvfhnktkelpraggehwsyglrpgggqyik anskfigitelgsgehwsyglrpggsglseikgvivhrlegprpegkpipnpllgldstrtghhhhh hstop

\section{Relative position of GnRH-I and T-helper epitopes in the vaccine}

Methionine-GnRH-I leader sequence-CSP-GnRH-I-RSV-GnRH-ITT-GnRH-I-Measles-GnRH-I leader sequence-CSP-GnRH-I-RSVGnRH-I-TT-GnRH-I-Measles-V5 epitope-Histidine tag-Termination

\section{Expression of GnRH-I fusion protein}

Previously engineered $[7,16]$ and newly constructed plasmid DNA vaccines were used to evaluate and compare transformation efficiencies. The undifferentiated COS1 cells in 24 well cell culture plates were transfected with $2 \mu \mathrm{g}$ plasmid DNA vaccines using Lipofectamine (Lipofectamine ${ }^{\text {Ta }}$ 2000, Life Technologies Inc. USA). Following 36 hours of transfection [16] the cell culture supernatant and the cell lysate were collected to detect GnRH-I fusion protein in Western blotting.

\section{Western blotting detection of fusion protein}

The fusion protein in the cell lysates and cell culture supernatant was electrophoresed on sodium dodecyl sulphate poly acrylamide gels for an hour [22]. A Kaleidoscope (Precision Plus Protein ${ }^{\mathrm{Tm}}$ BIO-RAD) protein marker was included in the starting wells and the separated protein bands in the gels were transferred to a nitrocellulose membrane (HybondTMECL membrane, Amersham Bioscience). The GnRH-I fusion proteins $[7,16]$ and newly designed on to the immunoblots were labelled with mouse monoclonal anti-GnRH-I antibody (Santa Cruz Biotechnology, USA) and anti-V5 antibody (Santa Cruz Biotechnology, USA). These antibodies were detected using Enhance Chemoluminoscence labeled anti-mouse IgG and X-ray imaging [23].

\section{Entrapped vaccine construct}

To entrap plasmid DNA vaccine, HVJE [19] and NISV [20] were used. The newly engineered plasmid DNA vaccine $(50 \mu \mathrm{g} / 50 \mu \mathrm{l}$ TE buffer) was entrapped in one agglutinating unit of HVJE vector (GenomONE-Neo Ex, Cosmo Bio Co., Ltd., Tokyo, Japan) and incubated on ice before priming of Group 2 mice. The NISV was prepared by using $136.4 \mathrm{mg}$ 1-monopalmitoyl glycerol (Sigma-Aldrich, UK), $128.7 \mathrm{mg}$ cholesterol (Sigma-Aldrich, UK) and $45.1 \mathrm{mg}$ dicetyl phosphate(Sigma-Aldrich, UK) with a molar ratio of 5:4:1. $2.5 \mathrm{mg}$ plasmid DNA vaccine was added in $5 \mathrm{ml}$ lipid preparation and entrapped plasmid DNA by repeated snap freezing and thawing $\left(60^{\circ} \mathrm{C}\right)$ for five cycles. Immediately before use, a tube containing $1.25 \mathrm{ml}$ vaccine formulation in NISV was retrived from liquid nitrogen, a further $2 \mathrm{~h}$ shaking at $60^{\circ} \mathrm{C}$ was carried out and the solution was centrifuged at $450000 \mathrm{~g}$ for $45 \mathrm{~min}$ to form finest vesicles containing entrapped DNA. The tube was incubated on ice until immunization was carried out.

\section{Immunization of mice}

Five weeks old Swiss albino female mice $(\mathrm{n}=24)$ were obtained from the International Center for the Diarrheal Disease Research, Bangladesh and housed in the laboratory animal containment facility of Bangladesh Agricultural University, Mymensingh, Bangladesh. Pelleted feed and water were supplied at lib and was replenished twice daily. At the age of week seven, the mice were randomized, caged into groups of eight and ear coded. The mice were immunized with $50 \mu \mathrm{g}$ plasmid DNA vaccine/mouse in study weeks $0,3,6,9$ and 12. Group 1 mice were immunized imtramuscularly with $50 \mu \mathrm{g}$ naked plasmid DNA in $50 \mu \mathrm{l}$ PBS and served as controls. Group 2 mice were primed with the plasmid DNA vaccine in HVJE and subsequent boostings in muscle (anterior quadriceps) were carried out in $50 \mu \mathrm{PBS}$ ( $\mathrm{pH}$ 7.4). Group 3 mice were primed and boosted with $50 \mu \mathrm{g}$ plasmid DNA vaccine in NISV through subcutenious (s.c) route. Out of eight mice in each group, four were used for breeding experiments and four were 
Citation: Umme Kulsum Rima, Tadashi Kimura, Ayman M Gebril, Mohammad Taimur Islam, Abu Saleh Mahfuzul Bari, Valerie Anne Ferro, Mohammad Abu Hadi Khan (2015) Immunization of Female Mice with a Plasmid DNA Vaccine Coding Eight Repeats of Gonadotrophin Releasing Hormone (Gnrh-I) and Eight T-Helper Epitopes Suppress Fertility In Vivo. J Vaccines Vaccin 6: 282. doi:2157-7560.1000282

Page 3 of 7

used to evaluate immune responses and histologic alteration of ovaries and uterus.

\section{Host response of immunization}

The body weight gain, feeding, oestrous behaviours, gait, morbidity and mortality pattern, weight of ovaries (in $\mathrm{mg}$ ), gonadosomatal indices (GSI, mg of ovaries/100 gm body weight) [24] and histologic alteration of ovaries and uterus of the vaccinated and control mice were evaluated. In study week 26, vaginal cytology of mice was examined to detect phases of estrous [25]. In proestrous phase of estrous cycle (nucleated epithelial cells in vaginal cytology) the vaccinated and control mice were sacrificed by cervical dislocation, weight of ovaries were measured, ovaries and uteri were preserved in $10 \%(\mathrm{v} / \mathrm{v})$ buffered neutral formalin and stained with Hematoxylin and Eosin (H\&E) and Goldners trichome [7]. The number of ovarian follicles, healthy and regressing corpus luteum (CL) in ovaries and the number of uterine glands per uterine section using $10 \mathrm{X}$ and $100 \mathrm{X}$ microscopic objectives were recorded. The images were captured using an automated computer (Microimaging, Carl Zeiss, GmbH, Germany) connected to a microscope and ZEN lite 2012 software.

\section{Measure anti GnRH-I antibody response}

In study weeks $0,3,6,12$ and $24,100 \mu$ tail bleeds were carried out into heparinized capillary tubes (Selzer Labortechnik, Germany). Plasma was prepared by centrifugation at $200 \mathrm{~g}$ for $10 \mathrm{~min}$ and stored at $-20^{\circ} \mathrm{C}$ until an indirect enzyme linked immunosorbant assay (ELISA) was carried out [16]. A base line OD value of 0.474 or above (twice the $\mathrm{OD}$ value of negative control) was considered a positive anti-GnRH-I antibody response.

\section{Effect on in vivo fertility}

In study week 24, the vaccinated female mice (four in each group) were mated individually with male mice. Control male and female mice were also mated individually to compare the differences. Following 10 days of mating (as the duration of estrous in vaccinated females lasts for 09-10 days, data was not shown) the male mice were withdrawn from the females. Following 16 days of mating the females were sacrificed by cervical dislocation and the number of pups in the uteri of each mouse were recorded.

\section{Statistical analysis}

Data between control and experimental groups were analyzed (Duncan's Multiple Range Test) using the Statistical Package for Social Sciences version 17.0 (Chicago, IL, USA). A difference was considered significant at the $\mathrm{p}<0.05$ level. Data were reported as the mean \pm standard deviation (SD).

\section{Results}

Results of sequence analysis revealed that the vaccine construct containing eight repeats of GnRH-I, eight T-helper epitopes, an $\mathrm{N}$ terminal V5 epitope and a histidine tag before stop codon (Figure 1). The GnRH-I fusion protein open reading frame onto the vaccine contained 981 nucleic acid bases and 326 amino acids.

\section{Translation efficiencies of the vaccine}

The plasmid DNA vaccines were efficiently translated their fusion proteins in COS1 cells. Results of Western blotting showed that the previous [7] and newly designed vaccine constructs released GnRH-I fusion proteins ( $18.871 \mathrm{kd}$ and $35.216 \mathrm{kd}$ respectively) in cell culture supernatant. GnRH-I fusion protein of a previous vaccine [16] was seen in transfected COS 1 cells (17.138 kd) but remained undetected in the cell culture supernatant (Figure 2).

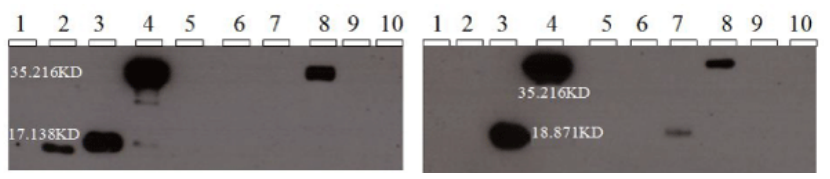

Figure 2: Western blotting detection of GnRH-I fusion protein obtained from transfected COS 1 cells and labelled with antiGnRH-I (left) and anti V5 antibodies (right). The first [10], second [6] and the new vaccines were used to transfect COS 1 cells. Lane 1 shows the Kaleidoscope ladder, lanes 2, 3 and 4 containing transfected COS1 cell lysate of the first, second and new vaccines respectively. Lanes 6, 7 and 8 containing transfected COS1 cell culture supernatant of the first, second and new vaccine repectively. Lane 5 and 9 containing non-transfected COS1 cell lysate and culture supernatant respectively (negative control) and lane 10 lacking both anti-GnRH-I (left) and anti V5 antibodies (right) in the Western blotting detection of the fusion protein. The newly engineered vaccine produce fusion protein $(35.216 \mathrm{KD})$ detected both in cell lysate (lane 4) and cell culture supernatant (lane 8). GnRH-I fusion protein $(17.138 \mathrm{KD}$ ) of the first vaccine (lane 2 ) was detected in the cell lysate (lane 6). GnRH-I fusion protein (18.871 $\mathrm{KD}$ ) of the second vaccine was detected both in cell lysate (lane 3) and cell culture supernatant (lane 7). GnRH-I fusion protein was not detected in any of the control lane 5, 9 and 10.

\section{Effect on growth and performance}

Mice immunized with the vaccine in vectors did not develope any agitation during the study period. There was significant reduction in the weight of ovaries in Group $2(8.50 \pm 2.38 \mathrm{mg}, \mathrm{p}>0.001)$ and Group 3 $(7.25 \pm 0.95 \mathrm{mg}, \mathrm{p}>0.001)$ mice in contrast to $15.00 \pm 1.41 \mathrm{mg}$ in Group 1 control. The GSI was reduced to $16.33 \pm 5.22$ and $12.44 \pm 2.02$ in Group 2 and 3 mice, respectively in contrast to $32.28 \pm 2.70$ in Group 1 control (Table 1).

\section{Detection of anti-GnRH-I antibodies}

Results of indirect ELISA showed an early anti-GnRH-I IgG antibody response in Group 2 mice $(0.451 \pm 0.231)$ following three weeks of immunization. The anti GnRH-I antibody response in Group 3 mice $(0.581 \pm 0.273)$ was detected in study week 6 . In study week 24 the anti-GnRH-I IgG antibody responses for Group 2 was $0.783 \pm$ 0.191 and Group 3 was $0.982 \pm 0.231$, compared with $0.237 \pm 0.147$ for Group 1 (Figure 3). 
Citation: Umme Kulsum Rima, Tadashi Kimura, Ayman M Gebril, Mohammad Taimur Islam, Abu Saleh Mahfuzul Bari, Valerie Anne Ferro, Mohammad Abu Hadi Khan (2015) Immunization of Female Mice with a Plasmid DNA Vaccine Coding Eight Repeats of Gonadotrophin Releasing Hormone (Gnrh-I) and Eight T-Helper Epitopes Suppress Fertility In Vivo. J Vaccines Vaccin 6: 282. doi:2157-7560.1000282

Page 4 of 7

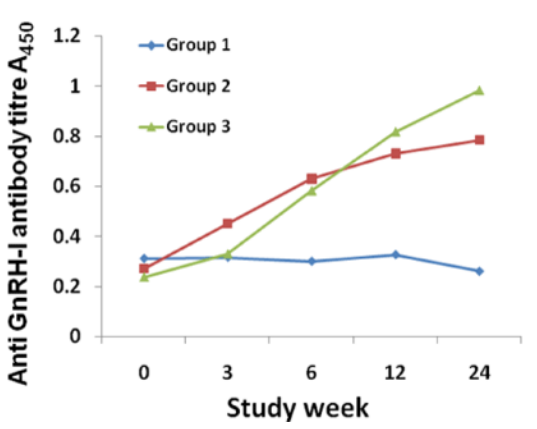

Figure 3: Results of an indirect ELISA to detect anti GnRH-I antibody response in control (Group 1) and vaccinated (Group 2 and 3) female mice. Plasma anti GnRH-I antibody response was detected in Group 2 mice $(0.451 \pm 0.231)$ in study week 3 . The anti GnRH-I antibody response in Group 3 mice $(0.581 \pm 0.273)$ was detected in study week 6 . By the end of the study (week 24) the anti GnRH-I antibody response appeared higher in Group $3(0.982 \pm$ $0.231)$ mice followed by Group $2(0.783 \pm 0.191)$ mice in contrast to a lack of response in Group 1 control $(0.237 \pm 0.147)$.

\section{Effect on ovarian folliculogenesis}

Following immunization, the growth and development of growing follicles, graffian follicles, healthy and regressing CL per section of ovaries (Figure 4$)$ were reduced. In study week 26 significant $(\mathrm{p}>0.01$ to 0.001 ) reduction in the count of growing follicles, graffian follicles, healthy CL and regressing CL of ovaries was seen in Group 3 and Group 2 mice (Table 1) in contrast to the Group 1 controls.

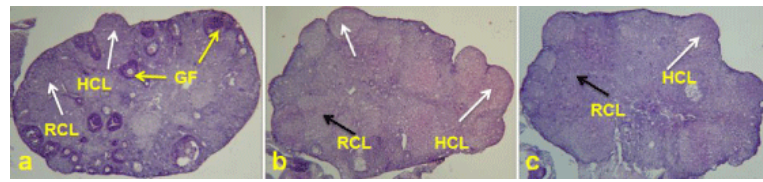

Figure 4: Histological evaluation of the ovaries of Group 1 (a), Group 2 (b) and Group 3 (c) mice obtained at terminal sacrifice and stained with $\mathrm{H} \& \mathrm{E}(10 \mathrm{X})$. There was significant $(\mathrm{p}>0.001)$ reduction in the count of graffian follicles (GF, $2.25 \pm 0.5$ ) in Group 2 mice. A reduction in the count of growing $(2.75 \pm 1.71)$ and graffian $(2.5 \pm$ 1.73) follicles in Group 3 mice (Table 1) was also seen as compared to growing $(6.5 \pm 2.65)$ and graffian follicles $(4.5 \pm 2.081)$ per section in Group 1 control (a) ovaries.

\section{Effect on uterine architecture}

Visible changes in the concentration of uterine glands in endometrium and thinness of myometrium were seen. In Group 1 mice the endometrium was enfolded in the lumen of the uterus (Figure 5). The endometrium of Group 2 and Group 3 mice were not folded in their lumen. While examining uterine section at $4 \mathrm{X}$ objective, the endometrium of Group 2 and Group 3 mice containing 8-15 uterine glands per section (Figure 5) compared with 40-50 uterine glands per sections in Group 1 control.

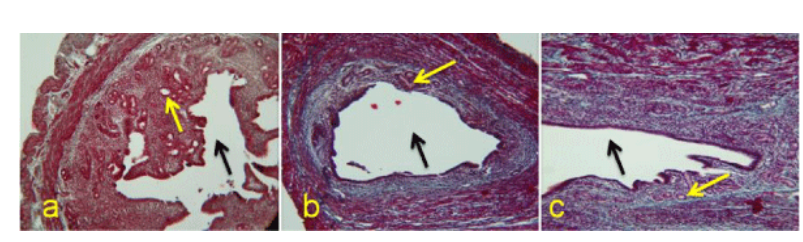

Figure 5: Histoarchitecture of uterine tissues of the control and vaccinated mice obtained at terminal sacrifice and stained with Goldners trichrome (4X). Immunization against GnRH-I found to reduce concentratoion of uterine glands (yellow). In an average 10-15 glands per uterine section in Group 2 (b) mice and 08-12 glands per section in Group 3 (c) mice was seen. The concentration of uterine glands (yellow arrow) appeared much higher in Group 1 (a, more than 40 glands per section) mice. The endometrium in control section (a) was repeatately folded in the lumen (black arrow) of uterus but were unfolded in Group 2 (b) and Group 3 (c) mice.

\section{Effect on in vivo fertility}

Results of in vivo fertility assay showed that half of the immunized mice (two in each group) were pregnant. All of the control mice appeared pregnant with $12-16$ pups per mice. Two pregnant mice in Group 2 and Group 3 were found to have 18 and 05 pups in their uteri respectively.

\section{Discussion and Conclusion}

Plasmid DNA vaccines are generally safe, non-toxic and have the potential to stimulate immune responses against hormones $[6,7,16]$. The low potency of plasmid DNA vaccines in large animals is that the injection of microgram doses of DNA results in the translation of only nanogram doses of protein [26] and most of the encoded proteins are not always released from the translation sites to the immune system [3]. Moreover, genetic immunization without a vector system is relatively inefficient $[1,16]$ as most of the DNA is rapidly internalized and cleared by macrophages [27]. Repeated administration of plasmid DNA is, therefore, required to increase the duration and level of transgene expression [28]. Numerous factors have been identified that influence immune responses to DNA vaccines included the choice of vector [29], promoter strength [30], amount of DNA delivered [31], DNA formulation [32], location of expressed antigens whether secreted or cytosolic [33] and co-expression of co-stimulatory molecules [34].

Previously we engineered plasmid DNA vaccines coding four [16] to five [7] repeats of GnRH-I and four T helper epitopes and obtained anti GnRH-I antibody responses. To acheive relative higher immunity, this study engineered a plasmid DNA vaccine coding eight repeats of GnRH-I. Here the key focus was to incorporate more GnRH-I. The Thelper epitopes were incorporated in the vaccine to acheive a Th-2 response. A V5 epitope from the feline immunodeficiency virus was incorporated in the vaccine construct, enabling fusion protein to be released following transfection (Figure 2). A histidine tag was added from the pcDNAV5HisB plasmid to extract the fusion protein following transfection and immunoneutralization of native GnRH-I in mammals using fusion protein. 
Citation: Umme Kulsum Rima, Tadashi Kimura, Ayman M Gebril, Mohammad Taimur Islam, Abu Saleh Mahfuzul Bari, Valerie Anne Ferro, Mohammad Abu Hadi Khan (2015) Immunization of Female Mice with a Plasmid DNA Vaccine Coding Eight Repeats of Gonadotrophin Releasing Hormone (Gnrh-I) and Eight T-Helper Epitopes Suppress Fertility In Vivo. J Vaccines Vaccin 6: 282. doi:2157-7560.1000282

Page 5 of 7

\section{Effect on growth and performance}

The mice tolerated well the plasmid DNA vaccine and there was insignificant difference in body weight gain by the end of this study. Group 3 mice developed little swelling at the injection sites and this was due to adjuvant effect of the vaccine [20]. Significance reduction in the weight of ovaries (Table 1) and GSI as seen in vaccinated mice was due to immunoneutralization of GnRH-I following vaccination $[5,7]$.

\begin{tabular}{|c|c|c|c|c|c|c|c|c|}
\hline \multirow{3}{*}{$\begin{array}{l}\text { Groups of } \\
\text { mice }\end{array}$} & \multicolumn{8}{|c|}{ Data represents were group average \pm SD } \\
\hline & \multicolumn{2}{|c|}{ Effect on ovaries and GSI } & \multicolumn{4}{|c|}{ Effect on ovarian follicles (number) } & \multicolumn{2}{|c|}{ Effect on CL (number) } \\
\hline & $\begin{array}{l}\text { Weight } \\
\text { ovaries }\end{array}$ & GSI & Premordial & Primary & Growing & Graffian & Healthy & Regressing \\
\hline Group 1 & $15.00 \pm 1.41$ & $208.00 \pm 4.320$ & $20.5 \pm 4.2$ & $5.25 \pm 1.71$ & $6.5 \pm 2.65$ & $4.5 \pm 2.081$ & $4.5 \pm 1.92$ & $6.25 \pm 1.26$ \\
\hline Group 2 & $8.5 \pm 2.38$ & $177.50 \pm 11.269^{*}$ & $17.25 \pm 4.11$ & $3.5 \pm 1.29$ & $2.75 \pm 1.71^{* * *}$ & $2.5 \pm 1.73^{* *}$ & $5.0 \pm 2.16$ & $4.5 \pm 1.29^{*}$ \\
\hline Group 3 & $7.2 \pm 0.957$ & $130.50 \pm 25.775^{* * *}$ & $18.25 \pm 2.22$ & 4.25 & $4.5 \pm 1.0^{*}$ & $2.25 \pm 0.5^{* * *}$ & $4.25 \pm 0.96$ & $4.75 \pm 1.71^{*}$ \\
\hline
\end{tabular}

Table 1: Level of oogenesis in vaccinated and control female mice as evaluated by the presence of different follicles and corpus luteum (CL) in the ovary at terminal sacrifice. Each stained section was examined at low (10X) and high (40X, 100X) power microscopic field, and the number of premordial, primary, growing and graffian follicles, healthy CL and regressing CL were counted and compared with that of untreated controls. Significant difference (** $\left.p>0.001,{ }^{*} \mathrm{p}>0.01\right)$ in the count of growing follicles, graffian follicles and regressing CL were seen in Group 2 and Group 3 mice compared to Group 1 control.

\section{Anti GnRH-I antibody response}

Genetic immunization against GnRH-I found to generate IgG immune responses which were higher in Group 2 and Group 3 mice. The highest anti-GnRH-I IgG antibody response as seen in Group 3 mice was most likely due to adjuvant effect of NISV [20]. The earliest immune response was detected in Group 2 mice (Figure 3) and was due to delivery of plasmid DNA vaccine in HVJE. The HVJE vector system has been developed to introduce plasmid DNA into various organs in vivo [19]. However, repeated administration of plasmid DNA vaccine with the antigenic vector system is not recommended as the antibodies developed against vector following priming could have neutralized the vector during subsequent boosting [35,36], thus preventing transfection of cells or tissues with the DNA vaccine construct. The subsequent boosting in Group 2 mice was, therefore, carried out in PBS, but the level of anti-GnRH-I antibody response in study week 24 was below the response as seen in Group 3 mice. The use of other vector(s) or NISV during the subsequent boosting in HVJE mediated immunization could potentiate a Th- 2 response, and requires further investigation.

\section{Effect on in vivo fertility}

Results of mating experiments revealed highest suppression of fertility in Group 3 mice, followed by Group 2 mice compared to Group 1 controls. Higher levels of anti-GnRH-I antibodies was detected in Group 2 and Group 3 mice and the number of pups in their uteri were low, a relationship between higher anti-GnRH-I antibody responses and suppressed in vivo fertility were co-rrelated. Level of folliculogenesis in the ovaries could have contributed to the fertility level of vaccinated mice as well.

\section{Effect on ovarian folliculogenesis}

The GnRH-I immunoneutralization studies showed suppression of ovarian folliculogenesis in vaccinated mice. There was significant reduction in the count of Graffian follicles in the ovaries of Group 2 ( $>00.001)$ and Group 3 ( $p>0.01$ ) mice (Table 1). Using H\&E staining structural morphology of growing and Graffian follicles in ovaries were seen, but the morphology of premordial and primary follicles were indistinct. However, use of Goldner's trichome staining the premordial and primary follicles were distinctly visible. The Goldners trichome staining enabled differentiation of healthy and regressing corpus luteum (CL) of ovaries by observing brick red color luteal cells of healthy $\mathrm{CL}$ and light pink color fibrosed body of regressing CL. The reduced in vivo fertility potential as seen in Group 2 and Group 3 mice could be due to suppression of folliculogenesis following GnRH-I immunoneutralization.

\section{Effect on uterine histoarchitecture}

Results of immunization showed its effect on to the densities of uterine glands in endometrium and thinness of uterine musculature (Figure 4). Highest level of anti GnRH-I antibody response was seen in Group 2 and Group 3 mice and highest reduction of uterine glands per section were seen in endometrium of Group 2 and Group 3 mice. Highest suppression of in vivo fertility was also seen in Group 2 and Group 3 mice. A state of endometrial inactivity as seen in vaccinated mice could have contributed to fertility suppression [37,38]. Bluish fibroid materials was seen in the uterine section of Group 2 and Group 3 mice and this could be due to uterine inertia or inactivity following GnRH-I immunoneutralization.

This study designed, engineered and evaluated a plasmid DNA vaccine aganist GnRH-I. The vaccine delivered in HVJE showed promising in terms of inducing an early immune response against GnRH-I, but in study week 24 the level of immune response appeared low because the subsequent boostings were carried out in PBS. The plasmid DNA vaccine delivered in NISV induced detectable levels of anti-GnRH-I antibody response in study week 6 and persistantly higher levels of IgG antibody were detected until study week 24 . The vaccine delivered in HVJE and NISV induced higher levels of antiGnRH-I antibody responses and suppressed ovarian folliculogenesis and impaired fertility in vivo. A link between the higher level of anti GnRH-I antibody response and suppressed fertility in mice was established. Priming of mice in HVJE vector and subseqent boosting in 
Citation: Umme Kulsum Rima, Tadashi Kimura, Ayman M Gebril, Mohammad Taimur Islam, Abu Saleh Mahfuzul Bari, Valerie Anne Ferro, Mohammad Abu Hadi Khan (2015) Immunization of Female Mice with a Plasmid DNA Vaccine Coding Eight Repeats of Gonadotrophin Releasing Hormone (Gnrh-I) and Eight T-Helper Epitopes Suppress Fertility In Vivo. J Vaccines Vaccin 6: 282. doi:2157-7560.1000282

Page 6 of 7

NISV could be a suitable approach for genetic immunization, that requires further investigation.

\section{Acknowledgements}

This work was supported by the Ministry of Science and Technology, Bangladesh. Thanks are due to Strathclyde Institute of Pharmacy and Biomedical Sciences, University of Strathclyde, Glasgow G4 ORE, UK for providing research and technical assistance. Part of this work was carried out in collaboration with the Department of Obstetrics and Gynecology, Osaka University Graduate School of Medicine, Osaka, Japan.

\section{References}

1. Wolff JA, Malone RW, Williams P, Chong W, Acsadi G, et al. (1990) Direct gene transfer into mouse muscle in vivo. Science 247: 1465-1468.

2. Cho HI, Niu G, Bradley N, Celis E (2008) Optimized DNA vaccines to specifically induce therapeutic CD8 $\mathrm{T}$ cell responses against autochthonous breast tumors. Cancer Immunol Immunother 57: 1695-1703.

3. Ulmer JB, Wahren B, Liu MA (2006) Gene-based vaccines: recent technical and clinical advances. Trends Mol Med 12: 216-222.

4. Shedlock DJ, Weiner DB (2000) DNA vaccination: antigen presentation and the induction of immunity. J Leukoc Biol 68: 793-806.

5. Jinshu X, Jingjing L, Duan P, Zheng Z, Ding M, et al. (2004) The immunogenicity of recombinant and dimeric gonadotrophin-releasing hormone vaccines incorporating a T-helper epitope and $\mathrm{GnRH}$ or repeated GnRH units. J Immunol Methods 289: 111-122.

6. Gupta JC, Raina K, Talwar GP, Verma R, Khanna N (2004) Engineering, cloning, and expression of genes encoding the multimeric luteinizing hormone-releasing hormone linked to $\mathrm{T}$ cell determinants in Escherichia coli. Protein Expr Purif 37: 1-7.

7. Khan MAH, Ogita H, Ferro VA, Kumasawa K, Tsutsui T, et al (2008) Immunisation with a plasmid DNA vaccine encoding gonadotrophin releasing hormone (GnRH-I) and T-helper epitopes in saline induces an anti-GnRH-I antibody response and suppresses rodent fertility. Vaccine 26: 1365-1374.

8. Stanislaus D, Pinter JH, Janovick JA, Conn PM (1998) Mechanisms mediating multiple physiological responses to gonadotropin-releasing hormone. Mol Cell Endocrinol 144: 1-10.

9. Fang FG, Yang YP, Liu Y, Zhang YH, Tao Y, et al. (2009) Immunization of Male Mice with a New Recombinant GnRH Fusion Protein Reduces the Testicular Function. Agric Sci China 8: 380-385.

10. Naz RK1, Gupta SK, Gupta JC, Vyas HK, Talwar AG (2005) Recent advances in contraceptive vaccine development: a mini-review. Hum Reprod 20: 3271-3283.

11. Killian G1, Miller L, Rhyan J, Doten H (2006) Immunocontraception of Florida feral swine with a single-dose GnRH vaccine. Am J Reprod Immunol 55: 378-384.

12. Jinshu X, Zheng Z, Jie W, Wentao L, Xiangchun S, et al. (2008) Immunization with a recombinant GnRH vaccine conjugated to heat shock protein 65 inhibits tumor growth in orthotopic prostate cancer mouse model. Cancer Lett 259: 240-250.

13. Ferro VA, Stimson WH (1997) Immunoneutralisation of gonadotrophin releasing hormone: a potential treatment for oestrogen-dependent breast cancer. Eur J Cancer 33: 1468-1478.

14. Jinshu X, Jinging L, Duan P, Zheng Z, Ding M, et al. (2005)Asynthetic Gonadotropin-Releasing Hormone ( $\mathrm{GnRH}$ ) vaccine for control of fertility and hormone dependent diseases without any adjuvant. Vaccine 23: 4834-4843.

15. Khan MAH, Ferro VA, Stimson WH (2003) Use of a highly specific monoclonal antibody against the central variable amino acid sequence of mammalian gonadotropin releasing hormone to evaluate GnRH-I tissue distribution compared with GnRH-I binding sites in adult male rats. AJRI 49: 239-248.

16. Khan MAH, Kimura T, Ferro VA, Koyama M, Koyoma S, et al.(2007) Immunisation of male mice with a plasmid DNA vaccine encoding gonadotrophin releasing hormone (GnRH-I) and T-helper epitopes suppresses fertility in vivo. Vaccine 25: 3544-3553.

17. Smorlesi A, Papalini F, Amici A, Orlando F, Pierpaoli S, et al. (2006) Evaluation of different plasmid DNA delivery systems for immunization against HER2/neu in a transgenic murine model of mammary carcinoma. Vaccine 24: 1766-1775

18. Widera G, Austin M, Rabussay D, Goldbeck C, Barnett SW, et al. (2000) Increased DNA vaccine delivery and immunogenicity by electroporation in vivo. J Immunol 164: 4635-4640.

19. Kaneda Y, Nakajima T, Nishikawa T, Yamamoto S, Ikegami H, et al. (2002) Hemagglutinating virus of Japan (HVJ) envelope vector as a versatile gene delivery system. Mol Ther 6: 219-226.

20. Gebril AM, Lamprou DA, Alsaadi MM, Stimson WH, Mullen AB, et al. (2014) Assessment of the antigen-specific antibody response induced by mucosal administration of a GnRH conjugate entrapped in lipid nanoparticles. Nanomedicine: Nanotechnology, Biology and Medicine 10: 971-979.

21. Raska M, Moldoveanu Z, Novak J, Hel Z, Novak L, et al. (2008) Delivery of DNA HIV-1 vaccine to the liver induces high and long-lasting humoral immune responses. Vaccine 26: 1541-1551.

22. Stott DI (1989) Immunoblotting and dot blotting. J Immunol Methods 119: 153-187.

23. García-Ortega P, Bartolomé B, Enrique E, Gaig P, Richart C (2001) Allergy to Diplotaxis erucoides pollen: occupational sensitization and cross-reactivity with other common pollens. Allergy 56: 679-683.

24. Ganaie JA, Gautam V, Shrivastava VK (2011). Effects of Kamdhenu Ark and Active Immunization by Gonadotropin Releasing Hormone Conjugate (GnRH-BSA) on Gonadosomatic Indices (GSI) and Sperm Parameters in Male Mus musculus. J Reprod Infertil 12: 3-7.

25. McLean AC, Valenzuela N, Fai S, Bennett SA (2012) Performing Vaginal Lavage, Crystal Violet Staining, and Vaginal Cytological Evaluation for Mouse Estrous Cycle Staging Identification. J Vis Exp e4389.

26. Huygen K (2005) Plasmid DNA vaccination. Microbes Infect 7: 932-938.

27. Abaitua F, Rodríguez JR, Garzón A, Rodríguez D, Esteban M (2006) Improving recombinant MVA immune responses: potentiation of the immune responses to HIV-1 with MVA and DNA vectors expressing Env and the cytokines IL-12 and IFN-gamma. Virus Res 116: 11-20.

28. Jang JH, Shea LD (2006) Intramuscular delivery of DNA releasing microspheres: microsphere properties and transgene expression. J Control Release 112: 120-128.

29. Pasquini S, Deng H, Reddy ST, Giles-Davis W, Ertl HC (1999) The effect of $\mathrm{CpG}$ sequences on the $\mathrm{B}$ cell response to a viral glycoprotein encoded by a plasmid vector. Gene Ther 6: 1448-1455.

30. Lee AH, Suh YS, Sung JH, Yang SH, Sung YC (1997) Comparison of various expression plasmids for the induction of immune response by DNA immunization. Mol Cells 7: 495-501.

31. Deck RR, DeWitt CM, Donnelly JJ, Liu MA, Ulmer JB (1997) Characterization of humoral immune responses induced by an influenza hemagglutinin DNA vaccine. Vaccine 15: 71-78.

32. Hartikka J, Bozoukova V, Ferrari M, Sukhu L, Enas J, et al. (2001) Vaxfectin enhances the humoral immune response to plasmid DNAencoded antigens. Vaccine 19: 1911-1923.

33. Drew DR, Lightowlers M, Strugnell RA (2000) Humoral immune responses to DNA vaccines expressing secreted, membrane bound and non-secreted forms of the Tania ovis $45 \mathrm{~W}$ antigen. Vaccine 18: 2522-2532.

34. Wang S, Farfan-Arribas DJ, Shen S, Chou TH, Hirsch A, et al. (2006) Relative contributions of codon usage, promoter efficiency and leader sequence to the antigen expression and immunogenicity of HIV-1 Env DNA vaccine. Vaccine 24: 4531-4540. 
Citation: Umme Kulsum Rima, Tadashi Kimura, Ayman M Gebril, Mohammad Taimur Islam, Abu Saleh Mahfuzul Bari, Valerie Anne Ferro, Mohammad Abu Hadi Khan (2015) Immunization of Female Mice with a Plasmid DNA Vaccine Coding Eight Repeats of Gonadotrophin Releasing Hormone (Gnrh-I) and Eight T-Helper Epitopes Suppress Fertility In Vivo. J Vaccines Vaccin 6: 282. doi:2157-7560.1000282

Page 7 of 7

35. Brun A, Albina E, Barret T, Chapman DAG, Czub M, et al. (2008) Antigen delivery systems for veterinary vaccine development: Viral-vector based delivery systems. Vaccine 26: 6508-6528.

36. Yang ZY, Wyatt LS, Kong WP, Moodie Z, Moss B, et al. (2003) Overcoming immunity to a viral vaccine by DNA priming before vector boosting. J Virol 77: 799-803.

37. Lloyd ML, Papadimitriou JM, O'Leary S, Robertson SA, Shellam GR (2010) Immunoglobulin to zona pellucida 3 mediates ovarian damage and infertility after contraceptive vaccination in mice. J Autoimmun 35: 77-85.

38. Tan SJ, Yeh YC, Shang WJ, Wu WJ, Liu JY, et al. (2010) Protective effect of a gonadotropin-releasing hormone analogue on chemotherapeutic agentinduced ovarian gonadotoxicity: A mouse model. Eur J Obstet Gynecol and Reprod Biol 149: 182-185. 